\title{
Insulin like growth factor-I, insulin like growth factor binding protein-1, and insulin in childhood Crohn's disease
}

\author{
A G Thomas, J M P Holly, F Taylor, V Miller
}

\begin{abstract}
Twenty nine children with Crohn's disease were studied before and after treatment with steroids or an elemental diet to assess the effect of disease activity and treatment on serum insulin like growth factor I (IGF-I), insulin like growth factor binding protein (IGFBP-1), and insulin concentrations. The median serum IGF-I concentration was lower in patients with active disease than in matched controls, and lower in stunted than well grown patients, but insulin and IGFBP-1 concentrations were not significantly different between any group. After four weeks of either treatment there was an increase in the median serum IGF-I concentration; this was greater in the steroid group than the elemental diet group. The median serum insulin concentration increased and median serum IGFBP-1 concentration decreased in the steroid treated group but not in the elemental diet group. These changes were accompanied by a greater and more sustained increase in energy intake in the steroid group. Despite this the median height velocity $\mathrm{SD}$ score was greater in the elemental diet group than in the steroid group.

(Gut 1993; 34: 944-947)
\end{abstract}

Growth failure is a major problem affecting up to $50 \%$ of children with Crohn's disease. ${ }^{1}$ Chronic dietary insufficiency is thought to be the single main cause but the mechanism is unclear. There are conflicting reports of spontaneous and stimulated growth hormone secretion in childhood Crohn's disease. McCaffery et al showed a blunted serum growth hormone response to insulin induced hypoglycaemia in 11 of 13 children with Crohn's disease and growth retardation and suggested that there might be a secondary pituitary abnormality. There was a normal serum growth hormone response in 10 children with Crohn's disease and normal growth ${ }^{2}$ but no obvious improvement in growth in three patients with growth failure treated with growth hormone. ${ }^{3}$ The authors suggested that this might represent end organ resistance to growth hormone. Gothin et al, studying six adolescents with inflammatory bowel disease and growth failure (three with Crohn's disease and three with ulcerative colitis), showed a normal sleep related serum growth hormone response in all six but a blunted response to arginine in one patient and to insulin in three patients. ${ }^{+}$Tenore et al also showed a significant serum growth hormone response during sleep and to propranolol/ glucagon but a poor response to insulin induced hypoglycaemia. ${ }^{5}$ Farthing et al have shown a low spontaneous nocturnal serum growth hormone concentration in three of five children with Crohn's disease and severe growth retardation, with a significant correlation between serum growth hormone concentration and the disease activity score. ${ }^{6}$ Kelts et al showed normal serum growth hormone (sleep and glucagon stimulation) and insulin like growth factor I (IGF-I) concentrations in seven children with Crohn's disease. ${ }^{7}$ Kirschner et al, on the other hand, showed low serum IGF-I concentrations in children with Crohn's disease. The serum concentration of IGF-I and growth velocity both improved with increased calorie intake. ${ }^{8}$

The insulin like growth factors are thought to mediate some of the effects of growth hormone on tissues. ${ }^{910}$ Infants with marasmus and kwashiorkor have low serum IGF-I concentrations despite high concentrations of growth hormone. The concentrations of both return to normal with refeeding. ${ }^{12}$ There is accumulating evidence that the action of IGF-I in target tissues is modulated by insulin like growth factor binding proteins (IGFBP) ${ }^{13}$ but there is a lack of published data in children with Crohn's disease. One of these binding proteins, IGFBP-1, is of particular interest because of its known relationship to metabolism. ${ }^{14}$

This study aimed to assess:

(1) The inter-relationships of serum IGF-I, IGFBP-1, and insulin in children with active Crohn's disease.

(2) The relationship of these parameters with nutritional status and treatment with steroids or an elemental diet.

\section{Patients and methods}

Twenty nine children with active Crohn's disease were studied. The mean age was $13 \cdot 2$ years (range 3.6-17.5) and the mean time from onset of disease was $2 \cdot 7$ years (range $0 \cdot 1-7 \cdot 9$ ). The diagnosis was confirmed by clinical, histological, and radiological appearances. Six patients had ileal involvement with or without caecal involvement (in two the proximal small bowel was also affected). One patient had disease that seemed to be confined to the proximal small bowel. Eleven patients had ileocolic disease and 11 had disease confined to the colon or anorectal region, or both. Disease activity was indicated by the following: increased stool frequency, abdominal pain, weight loss, growth failure, raised erythrocyte sedimentation rate (ESR), raised serum orosomucoid, and reduced serum albumin concentration. Activity was graded according to the Lloyd-Still activity index. ${ }^{15}$ Dietary intake was assessed by means of 
five day weighed surveys (Soelne digital scales) and analysed using McCance and Widdowson's: The Composition of Foods ${ }^{16}$ and a computer dietary analysis program (Microdiet, Salford University).

The children entered a randomised controlled trial and were allocated to one of two groups as follows:

Group A received a normal diet, sulphasalazine $25 \mathrm{mg} / \mathrm{kd} /$ day, and prednisolone $2 \mathrm{mg} / \mathrm{kd} /$ day (maximum $60 \mathrm{mg} /$ day). After two weeks the dosage of prednisolone was gradually reduced.

Group B received an elemental diet orally (Elemental 028, Scientific Hospital Supplies, Liverpool). Energy intake was adjusted to the estimated average requirement for healthy children of the same age - that is the recommended daily allowance (RDA). ${ }^{17}$ No other food or drink was allowed for four weeks, then normal foods were gradually reintroduced. Patients in whom there was a subsequent increase in disease activity were allocated to the alternative treatment group.

Height and weight were measured by the same observer (AT) in all patients at the time of study. Using the criteria of Waterlow, ${ }^{18}$ eight children (ages 11.5 12.7, 14.5, 11.6, 12.7, 12.8, 14.8, 16.2 years) were defined as stunted (less than $90 \%$ of expected height for age). Height velocity was measured for six months from the start of treatment and SD scores were calculated. ${ }^{19}$ The pubertal stage was rated as $1-5$, in the girls according to breast development and in the boys according to genital development following the criteria of Tanner..$^{20}$ Numbers of boys and girls within each pubertal group were as follows: stage 1, six boys:four girls; stage 2, three boys:one girl; stage 3 , three boys:one girl; stage 4 , no boys:two girls, stage 5 , seven boys:two girls.

Venous blood samples were collected after an overnight fast and the serum was immediately separated and stored at $-20^{\circ} \mathrm{C}$ until analysed. The serum IGF-I concentration was measured as previously described ${ }^{21}$ by radioimmunoassay (RIA) after acid ethanol extraction using a rabbit antiserum developed by $\mathrm{L} U$ Underwood and J J Van Wyk and distributed by the Hormone Distribution Program of NIDDK through the

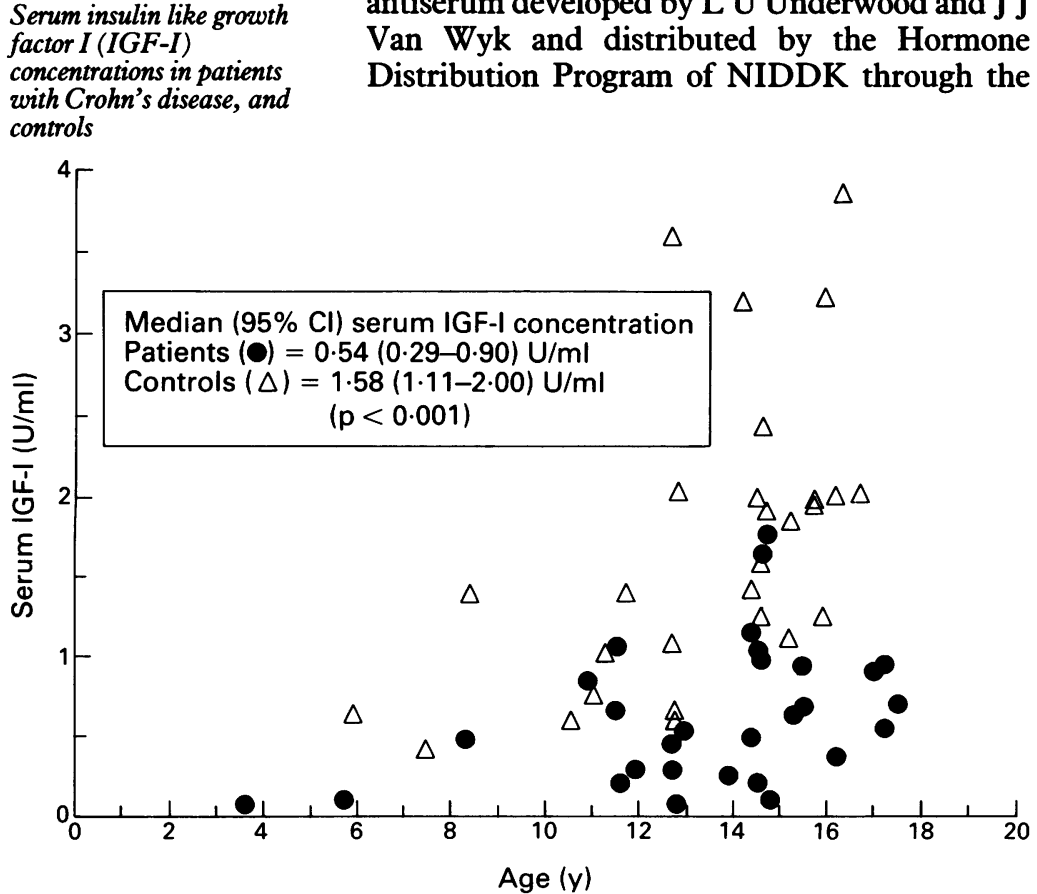

National Institutes of Health, Bethesda, MD, USA. The assay was standardised against a pool of normal adult human serum defined as containing $1.0 \mathrm{U} \mathrm{IGF}-\mathrm{I} / \mathrm{ml}$ (equivalent to $159 \mathrm{ng} / \mathrm{ml}$ of a highly purified preparation of IGF-I). Serum IGFBP-1 and insulin concentrations were measured by RIA as previously described. ${ }^{21}$

Serum IGF-I, IGFBP-1, and insulin concentrations were compared with those obtained from 29 age and sex matched controls selected from a large study of normal adolescents previously reported. ${ }^{22}$

Parametric data are expressed in terms of the mean and $95 \%$ confidence interval (CI) and comparison between groups was by the Student's $t$ test. Non-parametric data are expressed in terms of the median and lowest possible $\mathrm{CI}$ above $95 \%$ as calculated by the binomial based method, ${ }^{23}$ with comparison between groups by the MannWhitney U test.

\section{Results}

\section{IN RELAPSE}

Serum IGF-I concentrations in patients and matched controls are shown in the Figure. The median $(95 \% \mathrm{CI})$ serum IGF-I concentrations were $0.54(0.29-0.90) \mathrm{U} / \mathrm{ml}$ in patients compared with $1.58(1.11-2.00) \mathrm{U} / \mathrm{ml}$ in controls $(p<0.001)$. Twenty two patients had serum concentrations $<1.0 \mathrm{U} / \mathrm{ml}$ and 10 were $<0.4$ $\mathrm{U} / \mathrm{ml}$.

The median $(95 \% \mathrm{CI})$ serum insulin concentrations were $9 \cdot 3(5 \cdot 3-13 \cdot 0) \mathrm{mU} / \mathrm{l}$ in patients and $12 \cdot 0(11 \cdot 0-14 \cdot 0) \mathrm{mU} / 1$ in controls (NS), and median $(95 \% \mathrm{CI})$ serum IGFBP-1 concentrations were $55.0(41 \cdot 0-89.4) \mu \mathrm{g} / \mathrm{l}$ in patients and 57.0 $(42 \cdot 0-80 \cdot 0) \mu \mathrm{g} / \mathrm{l}$ in controls (NS). Two patients had very high insulin concentrations before starting treatment (161 and $213 \mathrm{mU} / \mathrm{l}$ ), suggesting that they were not adequately fasted. These data were not included in the analyses.

\section{EFFECT OF STUNTING (TABLE I)}

The median serum IGF-I concentration was significantly lower in stunted than well grown patients. Seven of the patients in the well grown group were sexually mature (Tanner stage 5), and excluding them had no significant effect on the median serum IGF-I concentration (reduced from 0.67 to $0.66 \mathrm{U} / \mathrm{ml}$ ). There were no significant differences between the median serum IGFBP-1 and insulin concentrations in well grown compared with stunted patients.

\section{CONTROLLED TRIAL (TABLE II)}

Median serum concentrations of IGF-I increased by $0.38 \mathrm{U} / \mathrm{ml}$ after four weeks' treatment $(0.54$ $0.92 \mathrm{U} / \mathrm{ml} ; \mathrm{p}<0.001)$. The median increase in the steroid treated group $(0.41 \mathrm{U} / \mathrm{ml})$ was significantly greater $(\mathrm{p}<0.05)$ than in the elemental diet group $(0 \cdot 1 \mathrm{U} / \mathrm{ml})$. In the steroid treated group, median fasting serum concentrations of insulin increased by $3.0 \mathrm{mU} / \mathrm{l}(\mathrm{p}<0.05)$ and median serum concentrations of IGFBP-1 fell by $27 \cdot 3 \mu \mathrm{g} / \mathrm{l}(\mathrm{p}<0 \cdot 01)$. Similar changes did not occur in the elemental diet group. 
TABLE I Serum insulin like growth factor I (IGF-I), IGF binding protein I (IGFBP-1), and insulin concentrations in well grown and stunted patients

\begin{tabular}{|c|c|c|c|c|c|}
\hline & \multicolumn{2}{|c|}{ Well grown } & \multicolumn{2}{|c|}{ Stunted } & \multirow[b]{2}{*}{$p$} \\
\hline & No & Median $(95 \% C I)$ & No & Median $(95 \% C I)$ & \\
\hline $\begin{array}{l}\text { IGF-I (U/ml) } \\
\text { IGFBP-1 }(\mu \mathrm{g} / \mathrm{l}) \\
\text { Insulin }(\mathrm{mU} / \mathrm{l})\end{array}$ & $\begin{array}{l}21 \\
20 \\
20\end{array}$ & $\begin{array}{c}0.67(0.48-0.94) \\
51.7(41.0-89.4) \\
7.95(5.3-13.0)\end{array}$ & $\begin{array}{l}8 \\
7 \\
7\end{array}$ & $\begin{array}{c}0.24(0.06-1 \cdot 13) \\
61.9(17.6-120 \cdot 3) \\
9.25(1.9-23.0)\end{array}$ & $\begin{array}{c}<0.02 \\
\text { NS } \\
\text { NS }\end{array}$ \\
\hline
\end{tabular}

TABLE II Changes in serum insulin like growth factor I (IGF-I), IGF binding protein 1 $(I G F B P-1)$, and insulin concentrations with treatment

\begin{tabular}{|c|c|c|c|c|c|c|c|c|}
\hline & \multicolumn{4}{|c|}{ Elemental diet } & \multicolumn{4}{|c|}{ Steroids } \\
\hline & No & Before & After & $p$ & No & Before & After & $p$ \\
\hline $\begin{array}{l}\text { Median IGF-I }(\mathrm{U} / \mathrm{ml}) \\
\text { Median IGFBP-1 }(\mu \mathrm{g} / \mathrm{l}) \\
\text { Median insulin }(\mathrm{mU} / \mathrm{l})\end{array}$ & $\begin{array}{r}13 \\
6 \\
6\end{array}$ & $\begin{array}{c}0 \cdot 45 \\
73 \cdot 5 \\
8 \cdot 9\end{array}$ & $\begin{array}{l}0 \cdot 55 \\
78 \cdot 5 \\
7 \cdot 1\end{array}$ & $\begin{array}{l}<0.001 \\
\text { NS } \\
\text { NS }\end{array}$ & $\begin{array}{r}16 \\
8 \\
7\end{array}$ & $\begin{array}{l}0 \cdot 65 \\
62 \cdot 6 \\
11 \cdot 0\end{array}$ & $\begin{array}{l}1 \cdot 06 \\
35 \cdot 3 \\
14 \cdot 0\end{array}$ & $\begin{array}{l}<0.001 \\
<0.01 \\
<0.05\end{array}$ \\
\hline
\end{tabular}

\section{GROWTH VELOCITY}

Increased disease activity occurred in six patients from the steroid group and in three from the elemental diet group before six months had elapsed. As they were allocated to the alternative treatment group their height velocities were not included in the analyses. The median height velocity $S D$ scores in the remaining patients were significantly greater in the elemental diet group $(+0.32)$ than the steroid group $(-3 \cdot 1 ; p<0 \cdot 05)$.

\section{DIETARY INTAKE}

Mean energy intake (Table III) was not significantly different in the two groups before treatment, increased in both groups after four weeks' treatment, and was maintained in the steroid treated group but not in the group treated with the elemental diet after 13 weeks.

\section{Discussion}

One of the most distressing aspects for children with Crohn's disease is the effect on growth. In the current study, $28 \%$ of the children had growth failure ( $<90 \%$ expected height for age). Several treatments have been shown to improve growth in children with Crohn's disease but it is crucial that catch up growth is achieved before the pubertal growth spurt is completed. Sanderson $e t$ al showed that an elemental diet was as effective as steroids in acute childhood Crohn's disease and also resulted in improved growth. ${ }^{24}$ Energy intake, however, was not measured. The current study confirms the improvement in linear growth velocity with an elemental diet despite a more sustained increase in energy intake with steroids.

This study also confirms the presence of low serum IGF-I concentrations in children with Crohn's disease, which may reflect depressed

TABLE III Energy intake in the two treatment groups

\begin{tabular}{lcclll}
\hline & \multicolumn{2}{l}{ Elemental diet $(n=13)$} & & \multicolumn{2}{l}{ Steroids $(n=16)$} \\
\cline { 2 - 3 } \cline { 5 - 6 } & $\begin{array}{l}\text { Mean } \\
(\% R D A)\end{array}$ & $(95 \% C I)$ & & $\begin{array}{l}\text { Mean } \\
(\% R D A)\end{array}$ & $(95 \% C I)$ \\
\hline Week 0 & 85 & $(68-102)$ & & 84 & $(76-92)$ \\
Week 4 & $102^{\star}$ & $(94-110)$ & & $124^{\star \star}$ & $(108-140)$ \\
Week 13 & 84 & $(74-94)$ & & $108^{\star}$ & $(94-122)$ \\
\hline
\end{tabular}

${ }^{\star} \mathrm{p}<0.05$ (compared with week 0 )

$\star_{\star \star} p<0 \cdot 01$ (compared with week 0 ). energy intake. Pubertal stage can have a major effect but the lower IGF-I concentrations in the children with growth failure could not be attributed solely to the greater proportion of sexually mature children in the well grown group. This finding supports previous reports of low serum IGF-I concentrations in growth retarded children with Crohn's disease, ${ }^{8}$ chronic renal failure, ${ }^{25}$ and anorexia. ${ }^{26}$

Serum concentrations of IGFBP-1 were not significantly different from controls and were similar in patients with growth failure and those with normal growth. The physiological role of IGFBP-1 is not clearly understood, and indeed it may have different functions in different circumstances or different tissues. ${ }^{14}$

Evidence from cell culture work suggests that IGFBP-1 may be an important modulator of the cellular activity of the insulin like growth factors, and in diabetics increased inhibitory activity is associated with an increased concentration of IGFBP- $1 .{ }^{21}$ It is also recognised that IGFBP-1 is just one of at least six distinct binding proteins but the functions and inter-relationships of these are also uncertain.

Surprisingly, the median serum IGF-I concentration increased more in the steroid treated group despite better growth in the group treated with the elemental diet. Furthermore, the reduction in IGFBP-1 values after steroid treatment might have been expected to increase the availability of IGF-I for growth. It seems that the recognised growth suppressant effects of steroids ${ }^{27}$ over-ride any benefits from increased energy intake, increased IGF-I concentration, and reduced IGFBP-1 concentration.

The increase in the serum insulin concentration after steroid treatment may reflect increased energy intake or induction of insulin resistance. The close inverse relationship between insulin and IGFBP-1 is well recognised in normal and diabetic children..$^{21}$ In most situations this seems to be a direct effect of insulin on the hepatic production of IGFBP-1. ${ }^{14}$

Further work is required to understand the complex relationship between energy intake, disease activity, the insulin-like growth factors, their binding proteins, and growth in children with Crohn's disease.

Dr Thomas was a clinical research fellow with the Crohn's in Childhood Research Association. We are very grateful to the North West Regional Health Authority and Scientific Hospital Supplies (Liverpool) for financial support.

1 Chong SKF. Crohn's disease in childhood. BMf 1982; 284: 101-3.

2 McCaffery TD, Nasr K, Lawrence AM. Severe growth retardation in children with inflammatory bowel disease. Pediatrics 1970; 45: 386-93.

3 McCaffery TD, Nasr K, Lawrence AM, Kirsner JB. Effect of administered human growth hormone on growth retardation in inflammatory bowel disease. Dig Dis 1974; 19: 411-6.

4 Gotlin DW, Dubois RS. Nyctohemeral growth hormone levels in children with growth retardation and inflammatory bowel in children with growth retar
disease. Gut 1973; 14: 191-5.

5 Tenore A, Berman WF, Parks JS, Bongiovanni AM. Basal and stimulated serum growth hormone concentrations in inflam matory bowel disease. F Clin Endocrinol Metab 1977; 44 622-8.

6 Farthing MJG, Campbell CA, Walker-Smith JA, et al. Nocturnal growth hormone and gonadotrophin secretion in growth retarded children with Crohn's disease. Gut 1981 22: 933-8.

7 Kelts DG, Grand JR, Shern G, et al. nutritional basis of growth failure in children and adolescents with Crohn's disease. Gastroenterology 1979; 76: 720-7.

8 Kirschner BS, Sutton MM. Somatomedin-C levels in growth impaired children and adolescents with chronic inflammatory bowel disease. Gastroenterology 1986; 91: 830-6. 
9 Phillips LS, Vassilopoulou-Sellin R. Somatomedins: part I. N Engl F Med 1980; 302: 371-80.

10 Phillips LS, Vassilopoulou-Sellin R. Somatomedins: part II. NEngl F Med 1980; 302: 438-46.

11 Hintz RL The

12 Mohan PS, Rao KSJ. Plasma somatomedin activity in protein calorie malnutrition. Arch Dis Child 1979; 54: 62-4.

13 Cianfarani S, Holly JMP. Somatomedin-binding proteins: what role do they play in the growth process. Eur $\mathcal{F}$ Pediat 1989; 149: 76-9.

14 Holly JMP. The physiological role of IGFBP-1. Acto Endocrinol (Copenh) 1991; 124: 55-62

15 Lloyd-Still JD, Green OC. A clinical scoring system for chronic inflammatory bowel disease in children. $D$ ig $D$ is $S c i$ 1979; 24: 620-4.

16 Paul AA, Southgate DAT. McCance and Widdowson's: the composition of foods. London, HMSO: 1978.

17 Department of Health and Social Security. Recommended daily amounts of food energy and nutrients for groups of people in the amounts of food energy and nutrients for groups of people in the subjects 15 .

18 Waterlow JC. Note on the assessment and classification of protein-energy malnutrition in children. Lancet 1973; ii: 87-9.

19 Tanner JM, Whitehouse RH, Takaishi M. Standards from birth to maturity for height, weight, height velocity, and weight velocity: British children, 1965. Part II. Arch Dis Child 1966; 41: 613-35.

20 Tanner JM, Whitehouse RH. Clinical longitudinal standards for height, weight velocity and stages at puberty. Arch Dis Child 1976; 51: 170-9.

21 Holly JMP, Dunger DB, Edge JA, Smith CP, Chard T, Wass JAH. Insulin-like growth factor binding protein-1 levels in diabetic adolescents and their relationship to metabolic diabetic adolescents and their relationsh.
control. Diabetic Medicine 1990; 7: 618-23.

22 Smith CP, Dunger DB, Williams AJK, et al. Relationship between insulin, insulin-like growth factor-I and dihydroepiandrosterone sulfate concentrations during childhood puberty and adult life. $\mathcal{F}$ Clin Endocrinol Metab 1989; 68: 932-7.

23 Campbell MJ, Gardner MJ. Calculating confidence intervals from some non-parametric analyses. In: Gardner MJ, Altman DG, eds. Statistics with confidence - confidence intervals and statistical guidelines. London: British Medical Journal, 1989: 71-9.

24 Sanderson IR, Udeen S, Davies PSW, et al. Remission induced by an elemental diet in small bowel Crohn's disease. Arch Dis Child 1987; 61: 123-7.

25 Winters RJ, Philips LS, Green OC, Traisman HS Somatomedin activity in the Mauriac syndrome. $\mathcal{F}$ Pediatr 1980; 97: 598-600.

26 Rappaport R, Prevot C, Czernichow P. Somatomedin activity and growth hormone secretion I. Changes related to body weight in anorexia nervosa. Acta Pediatr Scand 1980; 69: 37 41 .

27 Friedman M, Strang LB. Effect of long term corticosteroids and corticotrophin on the growth of children. Lancet 1966; ii: $568-72$. 